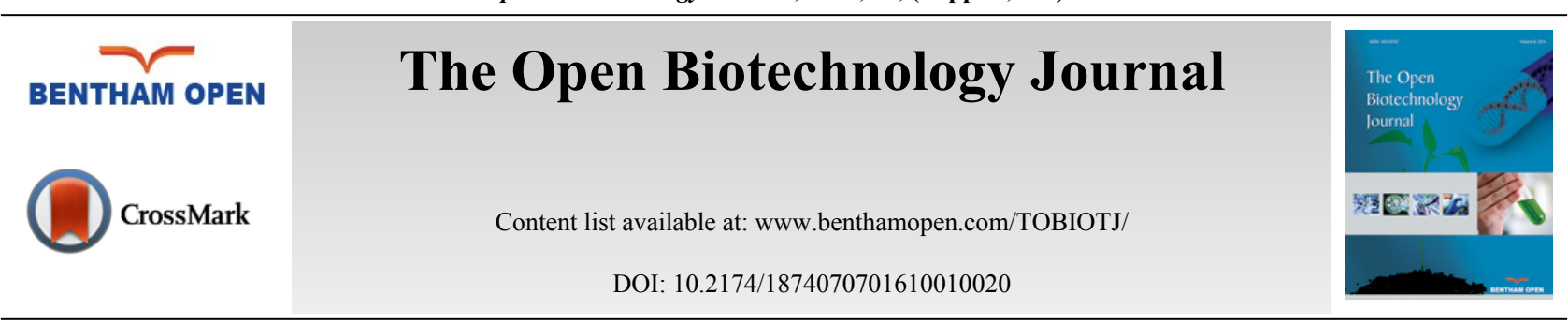

\title{
Endocrine Disruption in the Omics Era: New Views, New Hazards, New Approaches
}

\author{
Eva Oliveira, Carlos Barata and Benjamin Piña* \\ Department of Environmental Chemistry, Institute of Environmental Assessment and Water Research (IDAEA-CSIC), \\ Jordi Girona 18, 08034 Barcelona, Spain
}

\begin{abstract}
The genome revolution has brought about a complete change on our view of biological systems. The quantitative determination of changes in all the major molecular components of the living cells, the "omics" approach, opened whole new fields for all health sciences, including toxicology. Endocrine disruption, i.e., the capacity of anthropogenic pollutants to alter the hormonal balance of the organisms, is one of the fields of Ecotoxicology in which omics has a relevant role. In the first place, the discovery of scores of potential targets in the genome of almost any Metazoan species studied so far, each of them being a putative candidate for interaction with endocrine disruptors. In addition, the understanding that ligands, receptors, and their physiological functions suffered fundamental variations during animal evolution makes it necessary to assess disruption effects separately for each major taxon. Fortunately, the same deal of knowledge on genes and genomes powered the development of new high-throughput techniques and holistic approaches. Genomics, transcriptomics, proteomics, metabolomics, and others, together with appropriate prediction and modeling tools, will mark the future of endocrine disruption assessment both for wildlife and humans.
\end{abstract}

Keywords: Chemicals, endocrine disruption, hormone, metabolomics, proteomics, risk assessment, transcriptomics.

\section{INTRODUCTION - THE "OMICS" PERSPECTIVE}

The completion of the Human Genome Project in 2001 represented a complete turning point in Biology. Together with the complete genomes of the yeast Saccharomyces cerevisiae (1996), the nematode Caenorhabditis elegans (1998), the fruitfly Drosophila melanogaster (2000), the cress Arabidopsis thaliana, and the fish Takifugu rubripes (2002), it allowed for the first time the analysis of the genetic makeup of Eukaryotes in its complete extension and to establish new functional, evolutive and physiological correlations between taxa, individuals, organs and cell types. The development of new highly efficient analytical techniques has allowed similar holistic approaches for essentially all components of the live cell. For example, following the biological flow of information, high throughput techniques of specific RNA quantitation (microarrays) allowed the description of the mRNA complement of a given cell or tissue, i.e., the description of its transcriptome. A similar approach, but using completely different methods (2D electrophoresis, advanced mass spectrometry techniques), has been applied to elucidate the protein composition (the "proteome") with unprecedented precision, whereas several analytical methodologies (gas and liquid chromatography coupled to mass spectrometry, capillary electrophoresis, and high resolution nuclear magnetic resonance (NMR) allow the description of the chemical composition of the cell, that is, the nature and composition of its metabolites (the "metabolome"). Fig. (1) summarizes the nature and challenges of each one of these "omic" analyses.

The application of "omics" tools/technologies is now widely employed in many research areas, from medicine to environmental sciences, as they give information on some key regulators of various processes in living organisms. They also represent a tremendous opportunity to improve human and wildlife health by the characterization of the environmental elements that impact public and wildlife health [1]. The recognition of these challenges and

\footnotetext{
* Address correspondence to this author at the IDAEA-CSIC, Jordi Girona 18, 08034 Barcelona, Spain; Tel: 34934006157 ; Fax: 34 93204 5904; E mail: bpcbmc@cid.csic.es
} 
opportunities, along with the fact that many of the most prevalent diseases are associated with the endocrine system, has led to a focus on chemical exposures and especially endocrine disruptors. The term ecotoxicogenomics refers to the integration of genomic-based science into ecotoxicology using DNA array-based technologies, proteome and metabolomic analyses [2]. The approach has been fundamental in several aspects of our current comprehension of the effects of endocrine disruption: The elucidation of potential effects on different animal taxa, thanks to comparative genomics, the comprehension of the multiple targets for exogenous ligands in the cell, and the development of new and more precise methodologies to monitor endocrine disruption both in humans and in wildlife.

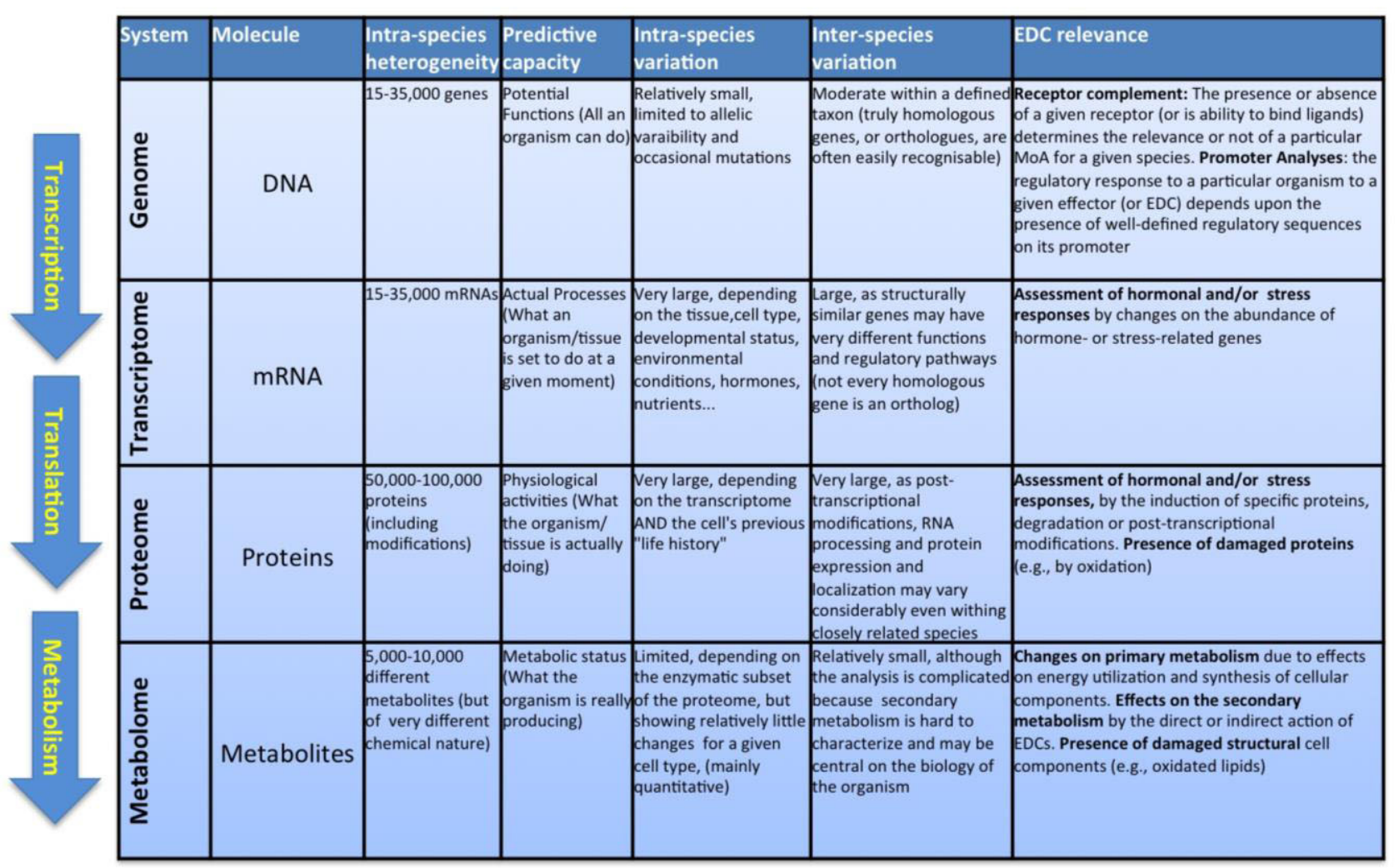

Fig. (1). Overview on the generic processes that characterize the differences "omics" technologies. On the left, schematic representation of the Biological information flow from the genome to cellular phenotypes. From top to bottom, the information of DNA (genome) is first transcribed to mRNA (transcriptome), which is afterwards translated into proteins (proteome). A subset of proteins, the enzymes catalyse reactions that both consume and produce the different metabolites (metabolome). The main table summarizes different characteristics of each omic technique.

\section{HORMONES AND PHYSIOLOGICAL PROCESSES}

Hormone are endogenous molecules secreted by endocrine glands that travel through the blood stream and induce physiological effects on distant cells and tissues [3]. The mechanism by which hormones exert their actions on target cells remained obscure for decades, although the concept of the existence of an endogenous receptor responsible for the recognition of the hormone (the "ligand") and the triggering of the physiological changes derived from its presence dates from the early 70's [4]. The isolation and cloning of the first hormone receptors in the 80's opened the Molecular Endocrinology era $[5,6]$. However, the recognition of the amazing complexity and implication of the hormonal signaling did not appear until the advancement of whole genome sequencing techniques and its extension to evolutionary distant species $[6,7]$. Analysis of complete genomes of different species revealed the presence of dozens, if not hundreds, of evolutionary related proteins for which no ligand or function was known. These so-called "orphan" receptors are widespread across Metazoa and their functional characterization implicated a major progress on the understanding of cell regulation, development and even evolutionary links between animal taxa [6 - 8]. An overview of the different receptor families, their physiological ligands and their distribution among the major Metazoan taxa is shown in Table $\mathbf{1}$. 


\section{ENDOCRINE DISRUPTION}

Environmental pollutants in the various ecosystems are a major concern worldwide. Our understanding of the potential adverse effects of anthropogenic contaminants has driven to an increasing public awareness on their influence on health and well-being of both humans and wildlife [3,9]. The primary observed effects of those pollutants are related to several developmental and reproductive disorders in wildlife species, which have been clearly linked to environmental compounds that act as endocrine disrupting chemicals (EDCs) [3].

By definition "An endocrine disruptor is an exogenous substance or mixture that alters function(s) of the endocrine system and consequently causes adverse health effects in an intact organism, or its progeny, or (sub) populations" [10]. Reports of adverse effects by EDCs in the last decades include reproductive impairment (decrease fertility, hermafroditism and sex reversal, altered sex ratios, hatching success), metabolic defects (Thyroid dysfunction, body weight and fat tissue control alteration), and alteration of immunological and behavioural functions have been observed in wild populations of mammals, birds, reptiles, amphibians, fish and mollusks; epidemiological evidences indicate that at least part of these or similar effects may be already occurring in human populations [3, 10 - 14].

Table 1. Nuclear receptors and their known ligands. Linkage between the nuclear receptors and their existence in animal taxa.

\begin{tabular}{|c|c|c|c|c|}
\hline Common Name & Abbreviation & Unified Name & Ligands (Mammalian) & $\begin{array}{l}\text { Taxonomic } \\
\text { Distribution }\end{array}$ \\
\hline $\begin{array}{l}\text { Dosage-sensitive sex reversal-adrenal hypoplasia } \\
\text { congenital critical region on the } \mathrm{X} \text { chromosome, gene } 1\end{array}$ & DAX-1 & NR0B1 & & $\mathrm{V}, \mathrm{Ar}$ \\
\hline Short heterodimeric partner & SHP & NR0B2 & & $\mathrm{V}, \mathrm{Ar}$ \\
\hline Thyroid hormone receptor $\alpha$ & $\mathrm{TR} \alpha$ & NR1A1 & thyroid hormones & V, UC, Mol, Ann \\
\hline Thyroid hormone receptor $\beta$ & $\mathrm{TR} \beta$ & NR1A2 & thyroid hormones & $\mathrm{V}, \mathrm{UC}, \mathrm{Mol}, \mathrm{Ann}$ \\
\hline Retinoic acid receptor $\alpha$ & RAR $\alpha$ & NR1B1 & retinoic acids & $\mathrm{V}, \mathrm{UC}$ \\
\hline Retinoic acid receptor $\beta$ & RAR $\beta$ & NR1B2 & retinoic acids & $\mathrm{V}, \mathrm{UC}$ \\
\hline Retinoic acid receptor $\gamma$ & $\mathrm{RAR} \gamma$ & NR1B3 & retinoic acids & $\mathrm{V}, \mathrm{UC}$ \\
\hline Peroxisome proliferator-activated receptor $\alpha$ & PPAR $\alpha$ & NR1C1 & fatty acids & $\mathrm{V}, \mathrm{UC}$ \\
\hline Peroxisome proliferator-activated receptor $\beta / \mathrm{d}$ & $\mathrm{PPAR} \beta / \delta$ & NR1C2 & fatty acids & $\mathrm{V}, \mathrm{UC}$ \\
\hline Peroxisome proliferator-activated receptor $\gamma$ & PPARg & NR1C3 & fatty acids & $\mathrm{V}, \mathrm{UC}$ \\
\hline Reverse-Erb $\alpha$ & REV-ERB $\alpha$ & NR1D1 & [heme] & $\mathrm{V}, \mathrm{UC}, \mathrm{Ar}$ \\
\hline Reverse-Erb $\beta$ & REV-ERB $\beta$ & NR1D2 & [heme] & $\mathrm{V}, \mathrm{UC}, \mathrm{Ar}$ \\
\hline RAR-related orphan receptor $\alpha$ & $\mathrm{ROR} \alpha$ & NR1F1 & [sterols] & $\mathrm{V}, \mathrm{UC}, \mathrm{Ar}$ \\
\hline RAR-related orphan receptor $\beta$ & ROR $\beta$ & NR1F2 & [sterols] & $\mathrm{V}, \mathrm{UC}, \mathrm{Ar}$ \\
\hline RAR-related orphan receptor $\gamma$ & $\mathrm{ROR} \gamma$ & NR1F3 & [sterols] & $\mathrm{V}, \mathrm{UC}, \mathrm{Ar}$ \\
\hline Liver $\mathrm{X}$ receptor $\beta$ & $\mathrm{LXR} \beta$ & $\mathrm{NR} 1 \mathrm{H} 2$ & oxysterols & $\mathrm{V}, \mathrm{UC}, \mathrm{Ar}$ \\
\hline Liver $\mathrm{X}$ receptor $\alpha$ & $\mathrm{LXR} \alpha$ & NR1H3 & oxysterols & $\mathrm{V}, \mathrm{UC}, \mathrm{Ar}$ \\
\hline Farnesoid X receptor $\alpha$ & $\mathrm{FXR} \alpha$ & NR1H4 & bile acids & $\mathrm{V}, \mathrm{UC}, \mathrm{Ar}$ \\
\hline Farnesoid $\mathrm{X}$ receptor $\beta \alpha$ & FXR $\beta$ & NR1H5 & & $\mathrm{V}, \mathrm{UC}, \mathrm{Ar}$ \\
\hline Ecdisone receptor & EcR & $\mathrm{NR} 1 \mathrm{H}$ & Ecdysone & Ar, Nem* \\
\hline Vitamin D receptor & VDR & NR1I1 & $\begin{array}{l}\text { 1a,25-dihydroxyvitamin D3 and } \\
\text { lithocholic acid }\end{array}$ & $\mathrm{V}, \mathrm{UC}, \mathrm{Ar}, \mathrm{Nem}$ \\
\hline Pregnane $\mathrm{X}$ receptor & PXR & NR1I2 & endobiotics and xenobiotics & $\mathrm{V}, \mathrm{UC}, \mathrm{Ar}, \mathrm{Nem}$ \\
\hline Constitutive androstane receptor & CAR & NR1I3 & xenobiotics & $\mathrm{V}, \mathrm{UC}, \mathrm{Ar}, \mathrm{Nem}$ \\
\hline Hepatocyte nuclear factor $4 \alpha$ & HNF4a & NR2A1 & [fatty acids] & $\mathrm{V}, \mathrm{UC}, \mathrm{Ar}, \mathrm{Nem}$ \\
\hline Hepatocyte nuclear factor $4 \gamma$ & HNF4g & NR2A2 & [fatty acids] & $\mathrm{V}, \mathrm{UC}, \mathrm{Ar}, \mathrm{Nem}$ \\
\hline Retinoid X receptor $\alpha$ & $\mathrm{RXR} \alpha$ & NR2B1 & $\begin{array}{l}\text { 9-cis retinoic acid and } \\
\text { docosahexanoic acid }\end{array}$ & $\mathrm{V}, \mathrm{UC}, \mathrm{Ar}, \mathrm{Mol}$ \\
\hline Retinoid X receptor $\beta$ & $\mathrm{RXR} \beta$ & NR2B2 & $\begin{array}{l}\text { 9-cis retinoic acid and } \\
\text { docosahexanoic acid }\end{array}$ & $\mathrm{V}, \mathrm{UC}, \mathrm{Ar}, \mathrm{Mol}$ \\
\hline Retinoid X receptor $\gamma$ & $\mathrm{RXR} \gamma$ & NR2B3 & $\begin{array}{l}\text { 9-cis retinoic acid and } \\
\text { docosahexanoic acid }\end{array}$ & $\mathrm{V}, \mathrm{UC}, \mathrm{Ar}, \mathrm{Mol}$ \\
\hline Testicular orphan receptor 2 & TR2 & $\mathrm{NR} 2 \mathrm{C} 1$ & & $\mathrm{~V}, \mathrm{UC}, \mathrm{Ar}, \mathrm{Nem}$ \\
\hline Tailless homolog orphan receptor & TLX & NR2E1 & & $\mathrm{V}, \mathrm{UC}, \mathrm{Ar}, \mathrm{Nem}$ \\
\hline Photoreceptor-cell-specific nuclear receptor & PNR & NR2E3 & & $\mathrm{V}, \mathrm{UC}, \mathrm{Ar}, \mathrm{Nem}$ \\
\hline
\end{tabular}




\begin{tabular}{|c|c|c|c|c|}
\hline Common Name & Abbreviation & Unified Name & Ligands (Mammalian) & $\begin{array}{l}\text { Taxonomic } \\
\text { Distribution }\end{array}$ \\
\hline $\begin{array}{l}\text { Chicken ovalbumin upstream promoter-transcription } \\
\text { factor } \alpha\end{array}$ & COUP-TF $\alpha$ & $\mathrm{NR} 2 \mathrm{~F} 1$ & & V, UC, Ar, Nem \\
\hline $\begin{array}{l}\text { Chicken ovalbumin upstream promoter-transcription } \\
\text { factor } b\end{array}$ & COUP-TF $\beta$ & $\mathrm{NR} 2 \mathrm{~F} 2$ & & $\mathrm{~V}, \mathrm{UC}, \mathrm{Ar}, \mathrm{Nem}$ \\
\hline $\begin{array}{l}\text { Chicken ovalbumin upstream promoter-transcription } \\
\text { factor } \gamma\end{array}$ & COUP-TF $\gamma$ & NR2F6 & & $\mathrm{V}, \mathrm{UC}, \mathrm{Ar}, \mathrm{Nem}$ \\
\hline Estrogen receptor $\alpha$ & $\mathrm{ER} \alpha$ & NR3A1 & estrogens & $\mathrm{V}, \mathrm{UC}^{*}, \mathrm{Mol}^{*}, \mathrm{Ann}$ \\
\hline Estrogen receptor $\beta$ & $\mathrm{ER} \beta$ & NR3A2 & estrogens & $\mathrm{V}, \mathrm{UC}^{*}, \mathrm{Mol}^{*}, \mathrm{Ann}$ \\
\hline Estrogen related receptor $\alpha$ & $\mathrm{ERR} \alpha$ & NR3B1 & & $\mathrm{V}, \mathrm{UC}, \mathrm{Ar}$ \\
\hline Estrogen related receptor $\beta$ & $\mathrm{ERR} \beta$ & NR3B2 & & $\mathrm{V}, \mathrm{UC}, \mathrm{Ar}$ \\
\hline Estrogen related receptor $\gamma$ & ERRg & NR3B3 & & $\mathrm{V}, \mathrm{UC}, \mathrm{Ar}$ \\
\hline Glucocorticoid receptor & GR & $\mathrm{NR} 3 \mathrm{C} 1$ & glucocorticoids & $\mathrm{V}$ \\
\hline Mineralocorticoid receptor & MR & NR3C2 & $\begin{array}{l}\text { mineralocorticoids and } \\
\text { glucocorticoids }\end{array}$ & $\mathrm{V}$ \\
\hline Progesterone receptor & PR & NR3C3 & progesterone & $\mathrm{V}$ \\
\hline Androgen receptor & $\mathrm{AR}$ & NR3C4 & androgens & $\mathrm{V}$ \\
\hline Nerve-growth-factor-induced gene B & NGF1-B & NR4A1 & & $\mathrm{V}, \mathrm{UC}, \mathrm{Ar}$ \\
\hline Nur-related factor 1 & NURR1 & NR4A2 & & $\mathrm{V}, \mathrm{UC}, \mathrm{Ar}$ \\
\hline Testicular orphan receptor 4 & TR4 & NR4A2 & & $\mathrm{V}, \mathrm{UC}, \mathrm{Ar}$ \\
\hline Neuron-derived orphan receptor 1 & NOR-1 & NR4A3 & & $\mathrm{V}, \mathrm{UC}, \mathrm{Ar}$ \\
\hline Steroidogenic factor 1 & SF-1 & NR5A1 & [phospholipids] & $\mathrm{V}, \mathrm{UC}, \mathrm{Ar}$ \\
\hline Liver receptor homolog-1 & LRH-1 & NR5A2 & [phospholipids] & $\mathrm{V}, \mathrm{UC}, \mathrm{Ar}$ \\
\hline Germ cell nuclear factor & GCNF & NR6A1 & & $\mathrm{V}, \mathrm{UC}, \mathrm{Ar}, \mathrm{Nem}$ \\
\hline
\end{tabular}

Ann- Annelida, Ar- Arthropoda, Mol- Mollusca, Nem- Nematode, UC- Urochordata/Cephalochordata, V- vertebrata

* No evidence for ligand binding. * Hypotetical

Ligands in brackets appear to be constitutively bound to their receptors

Data from reference [6], with modifications

There are varied sources of environmental contaminants that may disrupt the endocrine system (Fig. 2). The human exposure typically occurs with the environmental contamination of the food chain, especially fresh water fish and meat, contact with contaminated household dust, and occupational exposure [9]. Some chemicals were banned or removed from production years ago but persist in the environment. On the other hand other EDCs are high production volume chemicals found in a many household products. Bisphenol A (BPA), for example, is present in polycarbonate plastics, including beverage and food storage containers; epoxy resins that line the interior of metal cans, and in the ink used for thermal paper receipts. Many textiles contain contaminants, such as flame-retardants, including tetrabromobisphenol A and polybrominated diphenyl ethers. Some individuals have also been exposed to contaminants with adverse effects as a result of medical (diethylstilbestrol; DES), dental (diglycidyl methacrylate; GMA) or dietary (phytoestrogens) interventions. Urban wastewaters are important pollutant sources of natural and synthetic estrogens and other hormones that are subsequently found in surface waters $[15,16]$. Thus, exposure to EDCs is ubiquitous and inevitable and there is growing concern that living in an EDC contaminated world may be contributing to adverse health trends, such as early puberty and infertility, because of growing evidence that a number of EDCs can produce varied effects [3, 17], (Fig. 2).

\section{EVOLUTIONARY PERSPECTIVE OF ENDOCRINE DISRUPTION: EDCS IN INVERTEBRATES}

From its very first origins, the concept of endocrine disruption has been deeply associated to terrestrial vertebrate wildlife (birds, reptiles) and humans. However, environmental and laboratory research indicate that fish species are particularly sensitive to many forms of endocrine disruption, particularly to estrogens [18]. Finally, the discovery that the presence of TBT in coastal waters is linked to imposex in marine gastropods brought the same concept to mollusks and invertebrates in general $[19,20]$. The more recent deleterious effects of neonicotinoid insecticides on bee colonies around the world is probably a further example of the importance of recognizing and controlling environmental EDCs than can effect non-vertebrate species [21]. Nevertheless, information on EDCs in invertebrate species is still limited [22-30]. 


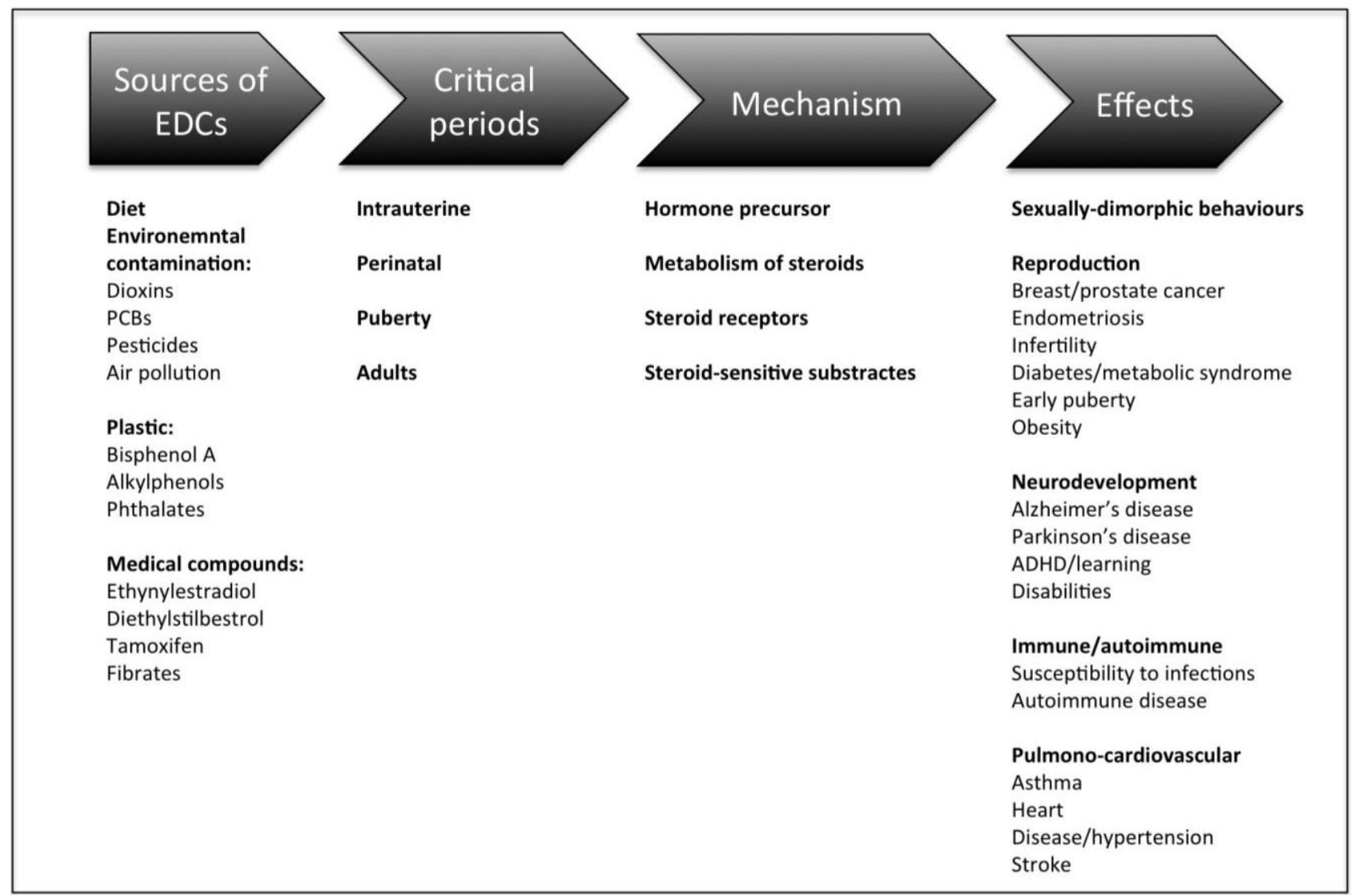

Fig. (2). Summary of the common sources and mechanisms of endocrine disruptors in humans and how they may influence some key developmental processes, in particular through their actions during critical periods of development.

Difficulties in performing invertebrate studies are largely due to the limited knowledge on the endocrine physiology of many invertebrate groups that represent important components of ecosystems. In the first place, the concept "invertebrate" is essentially instrumental, as it covers species from widely different Metazoans. Only among animals with bilateral symmetry (Bilateria), three major taxonomic clades appear: Deuterostomata (which includes Vertebrates and Echinoderms, among others), Ecdisozoa (Nematodes and Arthropods) and Spiralia/Lophotrochozoa (Mollusks and Annelids), the two later forming the group of Protostomata [31, 32] (Fig. 3). These major groups of animals, as well as the ancestral groups of Porifera and Ctenophora, are characterized by their distinct embryonic developments. Last advances on biochemistry, genome sequences and regulatory studies showed that they exhibit fundamental differences in their complements of nuclear receptors, in their ability to synthesize and metabolize molecules with ligand activity, and, most probably, in the physiological roles of these molecules (Fig. 3, Table 1) [8, 31 - 34].

Despite the great invertebrate genetic and taxonomic diversity, ecotoxicological studies are limited to few worms, mollusks and arthropod species that are easy to maintain and rear in the lab. Furthermore, in regard of their endocrine system, invertebrates have been relatively far less studied than vertebrates, with most of the literature published on invertebrate endocrinology referring to mollusks, insects and crustaceans [19, 34, 35]. When dealing with transcriptomic or proteomic analyses the situation is even worse, because of the relatively low number of invertebrate genomes at least partially sequenced and more or less correctly annotated [36, 37]. For these reasons there is a high degree of uncertainty to relate an adverse effect on invertebrate growth or reproduction to specific changes of its endocrine system. For example, despite the abundance of literature dealing with the development, growth and reproductive effects of EDC in invertebrates, only few studies have assessed unambiguously a truly endocrine disrupting effect [38]. Several studies tested the wrong premise that mammalian or vertebrate EDC should act as endocrine disruptors in invertebrates through identical or at least homologous mechanisms of action. This was especially evident for estrogenic/androgenic compounds tested against different arthropod species, which lack functional estrogenic/androgenic receptors (Table 1). In many cases, the detrimental effects of EDC on growth and reproduction reported, were related to egg mortality or feeding inhibition rather than to effects on endocrine disruption. 


\begin{tabular}{|c|c|c|c|c|c|}
\hline $\begin{array}{l}\text { Deuterostomia } \\
\text { Metazoa } \\
\text { Spiralia }\end{array}$ & & 1 & ] & I & t \\
\hline Ecdysozoa & & Steroids & $\begin{array}{l}\text { Amino Acid } \\
\text { Derivatives }\end{array}$ & Eicosanoids & $\begin{array}{c}\text { Peptides \& } \\
\text { Proteins }\end{array}$ \\
\hline & Porifera & $?$ & $?$ & $?$ & $?$ \\
\hline & Cnidaria & $?$ & + & ? & + \\
\hline & Ctenophora & ? & $?$ & $?$ & $?$ \\
\hline & Nematoda & + & $?$ & + & + \\
\hline & Arthropoda & + & + & + & + \\
\hline & Platyhelminthes & + & $?$ & + & $?$ \\
\hline & Nemertea & $?$ & $?$ & $?$ & + \\
\hline & Annelida & $?$ & $?$ & + & + \\
\hline & Echiura & $?$ & $?$ & $?$ & $?$ \\
\hline & Mollusca & + & + & + & + \\
\hline & Bryozoa & $?$ & $?$ & $?$ & $?$ \\
\hline & Echinodermata & + & + & + & + \\
\hline & Hemichordata & $?$ & $?$ & $?$ & $?$ \\
\hline & Urochordata & $+?$ & + & $?$ & + \\
\hline & Vertebrata & + & + & + & + \\
\hline & Cephalochordata & $?$ & $?$ & $?$ & $+?$ \\
\hline
\end{tabular}

Fig. (3). Presence of the different types of hormones among animals. Principal taxonomic groups are indicated. Signs “"+”' indicate that a given class of hormones has been demonstrated to be involved in life history transitions (LHT) for a particular taxon, "?", indicates that such a role has not been demonstrated, and “+?"' indicates preliminary evidence for such a roles (modified from [84]). The current model for evolutionary relationships among animal taxa is shown on the left (from [32]).

Research conducted in the crustacean species Daphnia provides conclusive evidence that juvenile hormone agonists enhanced male production disrupting the ultraspiracle receptor signaling pathway during the initial phases of embryo development [39]. There is also evidence that juvenile hormone agonists modulate ecdysteroid activity causing embryo arrest or abnormalities throughout the ultraspiracle- and ecdysone-receptor complex [40]. Studies on the effects of antidepressants show that molluscan and crustacean reproductive and locomotion systems are affected by antidepressants at environmentally relevant concentrations [35].

In particular, antidepressants affect spawning and larval release in bivalves and disrupt locomotion and reduce fecundity in snails. In crustaceans, antidepressants affect freshwater amphipod activity patterns, marine amphipod photo and geotactic behavior, crayfish aggression, and daphnid reproduction and development [34, 35, 41]. The above reported effects are likely to be related through out disruption of neuroendocrine signaling pathways. Like in vertebrates, the endocrine control of growth, reproduction and behavior in invertebrates are initiated by neurohormones [34, 35, 41]. Serotonin and antidepressants targeting these neurohormones induce spawning in bivalves, alter locomotion and foraging behavior in gastropods and alter mimetic and predatory behavior and memory in cephalopods [42 - 49]. 
A)

Low dose of methoprene

B)

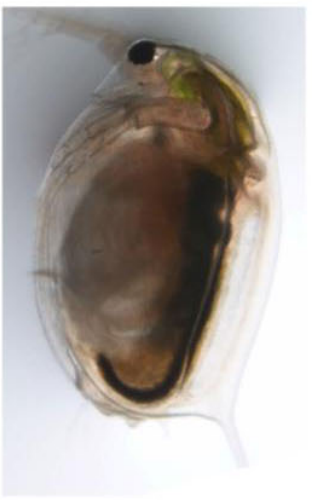

Control

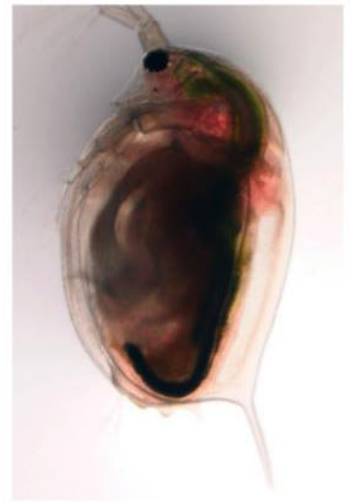

Treated

\section{FIGURE 4}

Fig. (4). (De)regulation of haemoglobin-related genes by juvenile hormone (JH) or its analogs (Methoprene, Methylfarnesoate, Fenoxycarb, and Epofenonene) in Daphnia magna. (A), Putative pathways of JH disruption (modified from [51]). (B) Example of the hemoglobin deregulated phenotype in D. magna by ectopic activation of the JH pathway.

Neurohormones control a wide variety of biological systems in crustaceans, including reproduction, growth, maturation, larval development, immune function, metabolism, behavior and colour physiology. For example, both serotonin and dopamine have been found to stimulate the release of multiple other crustacean neuropeptide hormones including hyperglycaemic hormone, red and black pigment dispersing/concentrating hormone, neurodepressing hormone, molt-inhibiting hormone and gonad-stimulating hormone [34, 41, 50, 51] (Fig. 4). Although neurohormonal disruption in molluscan and crustacean species have been mostly limited to antidepressants, there are other pharmaceutical drugs targeting neuronal receptors or other enzymes that may also alter neuroendocrinological pathways that regulate key physiological function. One of those are non-steroidal anti-inflammatory drugs (NSAIDs) that interrupt crustacean eicosanoid metabolism, which appears to disrupt signal transduction affecting juvenile hormone metabolism and oogenesis [52].

The implementation of omics approaches to invertebrates is limited to only few model species and studies that have addressed omics and EDCs are scarce [36, 37, 53 - 56]. Probably the best characterized and solidly established mode of action (MoA) of "canonical" (i.e., active in vertebrates) EDCs is the disruption of the enzymatic pathways for steroid synthesis, which are very well conserved within Metazoans [19, 57, 58]. However, several studies [53, 54, 56, 59 - 63] reported disruption on regulatory mechanisms in addition to the effects on the steroidogenic pathway. Transcriptomic patterns of intersex specimens of clams Scrobicularia plana showed a deregulation of the androgen receptor signaling pathway [53], an effect also described for Mya arenaria males exposed to TBT [64]. Metabolomic and proteomic analyses revealed different cases of neuroendocrine disruption in crustaceans and mollusks. For example, atrazine and its metabolites affected eicosanoids in the isopode Hyalella azteca suggesting possible perturbations in neuropeptide hormonal systems [55]. Similarly, ibuprofen inhibits reproduction in the crustacean Daphnia magna due to the de- 
regulation of the ecosanoid signaling pathway, and hence of prostaglandins, which in crustaceans control reproduction $[62,65]$. A typical vertebrate estrogenic EDC, ethinylestradiol, alters metabolite pathways related to energy reserves, signal transduction, immune response, and neuromodulation in the unionid mussel Lampsilis fasciola. These effects result in physiological changes, as altered siphon and mantle [54], both in male and females. Conversely, the polybromo-diphenyl ether congener (BDE 47) affects differentially male and female specimens of the marine mussel Mytilus galloprovincialis: males show effects in energy metabolism, whereas, in females, BDE 47 disrupts both osmotic regulation and energy metabolism [56].

Very likely, we are just beginning to understand the phenomenon of EDC in invertebrates, and many of the chemicals that are contaminating terrestrial, freshwater and marine ecosystem may have endocrine disrupting effects on invertebrate species. Given the vast genetic diversity of Metazoans, the MoA already defined for vertebrates may or may not apply to any particular taxon. Therefore, EDC toxic effects may have unanticipated, and many times unnoticed until they reach global scale, deleterious effects in the ecosystems that depend upon invertebrate populations.

\section{OMICS’ APPLICATION ON EDCS ASSESSMENT}

\section{Transcriptomics and EDCs}

The availability of studies that report the transcriptomic changes of different EDCs on several organisms, including human cells is reported in Table S1. One of the goals of the transcriptomic analysis is to discover mechanistically based molecular biomarkers with utility for risk assessment and develop modeling approaches for predicting adverse outcomes. The understanding of population-level impacts of EDCs in biological systems is, however, dependent on an enhanced knowledge of their MoA, and development of mechanism-based indicators suitable for application on field work that enable linkage of exposure to adverse effects at both individual and population levels.

The elucidation of the signaling pathways and transcription factors (TF) networks affected by EDCs could be successfully addressed by examining the transcriptomic responses in model species such as the zebrafish (Danio rerio). Among the several fish species with a sequenced genome, zebrafish is one of the best model systems for omics, which is addressed by considerable high number of studies, reporting the effects of EDCs in different tissues and in differential stages of development. In addition, it has relatively abundant genomic resources such as genetic maps, mutants, and markers available [66].

The biological responses to external stressors, including toxicants, involve changes in normal patterns of gene expression [67, 68]. Many responses are a direct result of the chemical, such as alterations in gene expression caused by the binding of a steroid hormone (or analogue) to a specific steroid hormone receptor, which acts as a TF and subsequently modulates (activates or represses) the transcription of its target genes. Importantly, however, different mechanisms of toxicity can generate specific patterns of gene expression that can potentially provide us with molecular biomarkers of disruption of a biological process and be reflective of mechanism or mode of action [67].

The search for networks, enabling new hypotheses to be formulated and tested for the mechanisms underlying specific toxic effects are one of the best challenges that transcriptomic is facing. From systems biology perspective, signaling pathways and TF networks are at the center of a complex biological system. As such, signal transducers and TFs provide critical links between chemical exposures and resultant toxic effects manifested at various levels of biological hierarchy, from molecular to organismic [69].

Mechanistically based molecular indicators would also allow for improved extrapolation of effects across species, biological levels of organization, and diverse chemical structures. Finally, given the pleiotropic nature of signal transducers and TFs, organismic endpoints explicitly mapped to specific toxicity mechanisms may be developed by generating gene knockout mutants in targeted pathways. An ensuing greater efficiency and accuracy in the assessment of both EDC exposure and hazard would improve the overall risk assessment process [69].

It should be emphasized, that changes in gene expression are generally rapid and thus potentially provide a capability of a rapid diagnosis of chemical effect. However, the transcription of messenger ribonucleic acid (mRNA) is only an intermediate step in conversion of genetic information into proteins, the biochemical bases of biological function and gene expression and concentration of functional proteins are not necessarily always directly related.

\section{Proteomics and EDCs}

Proteomics has gained popularity in the field of ecotoxicology as a holistic tool for unraveling novel mechanisms of 
toxicity and elucidating subtle effects of contaminant exposure. Proteomic analysis has been used in the field of ecotoxicology to identify new candidate biomarkers for environmental contaminants and stressors such as heavy metals, flame retardants, polyaromatic hydrocarbons, polychlorinated biphenyls, herbicides, pesticides, and anoxia [55]. Although several proteomic studies have included invertebrate species such as mollusks or crustacean; other studies focus on several vertebrates such as fish or even cell lines.

The subject of proteomics offers a potentially powerful approach to ecotoxicology, particularly with respect to providing biomarkers of environmental contamination. The challenges in measuring molecular changes include choosing the appropriate timing of sampling. Cost and logistical considerations often force experimental designs to trade-off between sufficient biological replicates and sampling at different time points. Multiple pathways and modes of action and limited temporal windows necessitate the evaluation of multiple levels of organization to better capture biological effects and to enhance predictive and diagnostic power. Tissue samples from test animals can be simultaneously collected from amenable tissues such as liver or tail fin for transcriptomic, proteomic, and metabolomic analyses. Initial proteomic studies utilized two-dimensional gel electrophoresis (2DGE) to identify changes in the patterns of protein expression under chemical stress, later on, other more sophisticated techniques has been applied. Liquid chromatography (LC) and mass spectrometry (MS) methodologies, along with the growth of available genome sequence information and powerful bioinformatics tools, facilitated protein separation and identification, and enhanced the knowledge from those studies. The number of publications recognized by "Scopus" document search, with the key words terms "endocrine disruption" plus "proteomics" showed only a total of 23 results in May 2014. The summary of the publications and their associated results are shown in Table $\mathbf{S 2}$.

\section{Metabolomics and EDCs}

As of May 2014, only 17 articles that combine metabolomic and endocrine disruption words appeared in the bibliographic database. This omic technology is advancing at a rapid pace and the resulting knowledge of biological responses has the potential to improve understanding of the molecular pathways that control physiological processes. The metabolome analysis is a method to detect changes in endogenous metabolites originating from biochemical pathways, such as amino acids, lipids, carbohydrates, hormones etc. It has been shown that changes to endogenous metabolites do reflect changes in the physiology and the phenotype of animals treated with test compounds. Therefore, elucidating how organisms respond to stressors, could aid regulatory policy and decision-making processes in chemical risk assessment. Although there are several challenges ahead in view of using such data for regulatory purposes (such as information interpretation and linking to adverse outcomes) the value of metabolomic platforms in the unraveling of the molecular processes involved in chemical toxicity, including endocrine disruption, is generally recognized. For example, metabolomics based technologies was applied to investigate EDCs toxicity (Table S3) in human cell lines, fish and mussels [54, $70-72]$.

\section{A Practical Approach: Predictive Endocrine Disruption}

Most international regulators posed as a major objective to stop the continuous deterioration of the environment by the thousands of new products entering into the marked each year. This objective demands multi-level, multi-tiered approaches, combining chemical analytical and biological methods [73]. Whereas the chemical identification of pollutants has advanced notoriously in recent years, allowing quantification of a wide array of potential pollutants in the environment at sub-ppb levels, the biological characterization of their putative effects on ecosystems and human health is clearly lagging behind in terms of defining new risks ("emerging pollutants"), identifying emerging effects of classical pollutants (behaviour, neurological, immunological or metabolic disorders, for example) or characterizing the mechanism of toxicity [74]. This is a most serious impediment for both the correct evaluation of environmental impacts and for the assessment of risks associated to new substances.

Toxicologists (including Ecotoxicologists) have developed different methods to evaluate the toxicity of new and well-known substances in order to evaluate their possible environmental and human health hazards either before they enter the marked or before their impact in human populations and wildlife exceeds their proved or assumed economic benefits. Classic toxicology relies heavily on the use of standard animal models to evaluate toxic effects, including rodents and dogs as surrogate for human populations, and fish, crustaceans, and algae to evaluate environmental hazards. This approach has two major limitations. First, they are slow and costly, taking several months and thousands of dollars to evaluate a single substance. And second, there is a quasi-universal claim to reduce animal suffering to the absolutely unavoidable minimum, by applying what is known as the 3Rs rules: replacement, reduction and refinement 
of animal experiments, [75]. Cell cultures, non-animal or non-vertebrate models (yeasts, crustaceans, annelida, nematodes), and free embryos before their autonomous stage have been proposed as valid alternatives to conventional animal testing for both toxicology and food and drug safety studies [76].

Within the general context of toxicology, endocrine disruption presents a further difficulty in their characterization in non-vertebrate models. For one thing, different animal taxa may encompass different complements of receptors, and therefore their susceptibility to a particular substance may differ wildly. In addition, the analysis of binding to a particular receptor, even accounting for species specificity, may not suffice to characterize an endocrine disruptor as such. Many estrogenic compounds do interact with the ER and, therefore, they are recognizable by single-cell or even in vitro or QSAR approaches. But this does not apply to those that affect steroid metabolism or others, like HCB, for which a suitable model of action has not been demonstrated [77]. And these problems increase when more "metabolic" signaling pathways, like thyroid, PPAR, retinoids, and others, in which the so-called non-genomic effects (effects on hormone metabolism, transport or degradation, neuroendocrine control, etc.) may easily shadow the more "classic", receptor-binding linked effects [57, 77 - 80].

\section{Ecological Relevance}

\begin{tabular}{|c|c|c|c|c|c|c|c|}
\hline \multirow[b]{3}{*}{$\begin{array}{l}\text { Organization } \\
\text { level }\end{array}$} & \multicolumn{7}{|c|}{ Ecological Relevance } \\
\hline & \multicolumn{7}{|c|}{ Predictive/Mechanistic Utility } \\
\hline & Chemical & $\begin{array}{l}\text { (Macro) Molecular } \\
\text { Interactions }\end{array}$ & Cellular responses & Organ responses & Organism responses & $\begin{array}{l}\text { Population } \\
\text { responses }\end{array}$ & Ecosystem effects \\
\hline & chemical properties & $\begin{array}{l}\text { Receptor/Ligand } \\
\text { binding }\end{array}$ & Gene Regulation & Altered Physiology & Lethality & $\begin{array}{l}\text { Extinction/ } \\
\text { Overpopulation }\end{array}$ & Loss of Biodiversity \\
\hline \multirow{5}{*}{$\begin{array}{l}\text { Apical } \\
\text { Endpoints }\end{array}$} & $\begin{array}{l}(\text { Kow, structure, } \\
\text { reactivity, pK...) }\end{array}$ & DNA binding & $\begin{array}{l}\text { Protein synthesis and } \\
\text { modification }\end{array}$ & $\begin{array}{l}\text { Hypertrofia/ } \\
\text { Degeneration }\end{array}$ & $\begin{array}{l}\text { Developmental } \\
\text { abnormalities }\end{array}$ & Altered age structure & $\begin{array}{l}\text { Disruption of trophic } \\
\text { chains }\end{array}$ \\
\hline & & $\begin{array}{l}\text { DNA, Protein or Lipid } \\
\text { damage }\end{array}$ & Altered signalling & Inflammation & Impaired reproduction & Alteration of sex ratios & Invasive species \\
\hline & & & & $\begin{array}{l}\text { Disruption of } \\
\text { Homeostasis }\end{array}$ & Tumor development & & \\
\hline & & & & & Behavioral alterations & & \\
\hline & Chemical analyses & In vitro binding assays & qRT-PCR & Histology & Toxicological assay & Population monitoring & Bioindicators \\
\hline \multirow{5}{*}{$\begin{array}{l}\text { Technical } \\
\text { Approaches }\end{array}$} & QSAR & Cell-based bioassays & Transcriptomics & Anatomical Pathology & Anatomical Pathology & $\begin{array}{l}\text { Microcosmos } \\
\text { experiments }\end{array}$ & Metagenomics \\
\hline & & Biochemical assays & Proteomics & Metabolical markers & Multigenerational tests & & Metatranscriptomics \\
\hline & & Proteomics & Metabolomics & Metabolomics & Anatomical Pathology & & Ecosystem monitoring \\
\hline & & Lipidomics & Lipidomics & Transcriptomics & Metabolical markers & & \\
\hline & & QSAR & & Proteomics & Behaviour tests & & \\
\hline
\end{tabular}

Fig. (5). Schematic representation of the proposed prediction model for the identification of mode of action and apical endpoints according to the adverse outcome pathway, which provides a causal linkage from a direct molecular initiating event and adverse outcomes (pink) at all levels of biological organization (red) used in risk assessment. Omics and other techniques relevant for each level of organization are also indicated (green).

Genomic and other omic techniques can be used to infer complex toxic effects, affecting higher levels of organization, from the analysis of a reduced number of well-controlled model species. The basic idea underlying this approach is that the signaling pathways are well conserved during evolution, so the determination of the effect of a given substance on a specific pathway on a model species is transferrable to humans or environmentally relevant species as long as the modes of action are known and the pathways from the molecular initiating effects and the final adverse effects are conserved. This translation of toxic effects through the different levels of biological organization is known as Adverse outcome pathway (AOP) analysis. In this approach, the different organization levels are analyzed, ranking the corresponding data according to their ecological relevance and its predictive capacity and mechanistic utility (Fig. 5) [69, 81]. Once identified, AOPs can be used to develop high throughput omic technology-based predictive assays, providing valuable information for human and environmental risk assessment. By comparing AOPs across species is possible to identify specific and shared mechanisms of toxicity, and hence use this information in 
understanding and managing environmental risks. Fig. (6) shows an example of the AOP approach and of its application in two cases of endocrine disruption, one in fish and a second in Daphnia [82, 83]. Note the central part of omic technologies in the process of ellucidating the mechanisms of toxicity for each type of disruption (ectopic expression of female proteins in males, disruption of carbohydrate metabolism).

\section{Concluding Remarks: The Need for a Synthetic Approach}

The "genome revolution" has modified forever the fundamentals of Biology. For the first time, quantitative approaches can be applied and modeled, using truly holistic points of view. In the field of Ecotoxicology, and particularly in the study of endocrine disruption, the knowledge of complete genomes from very different taxa discovered not only scores of new potential targets in the already know organisms, but also to predict or explain unsuspected effects in non-targeted, less known species of ecological significance.

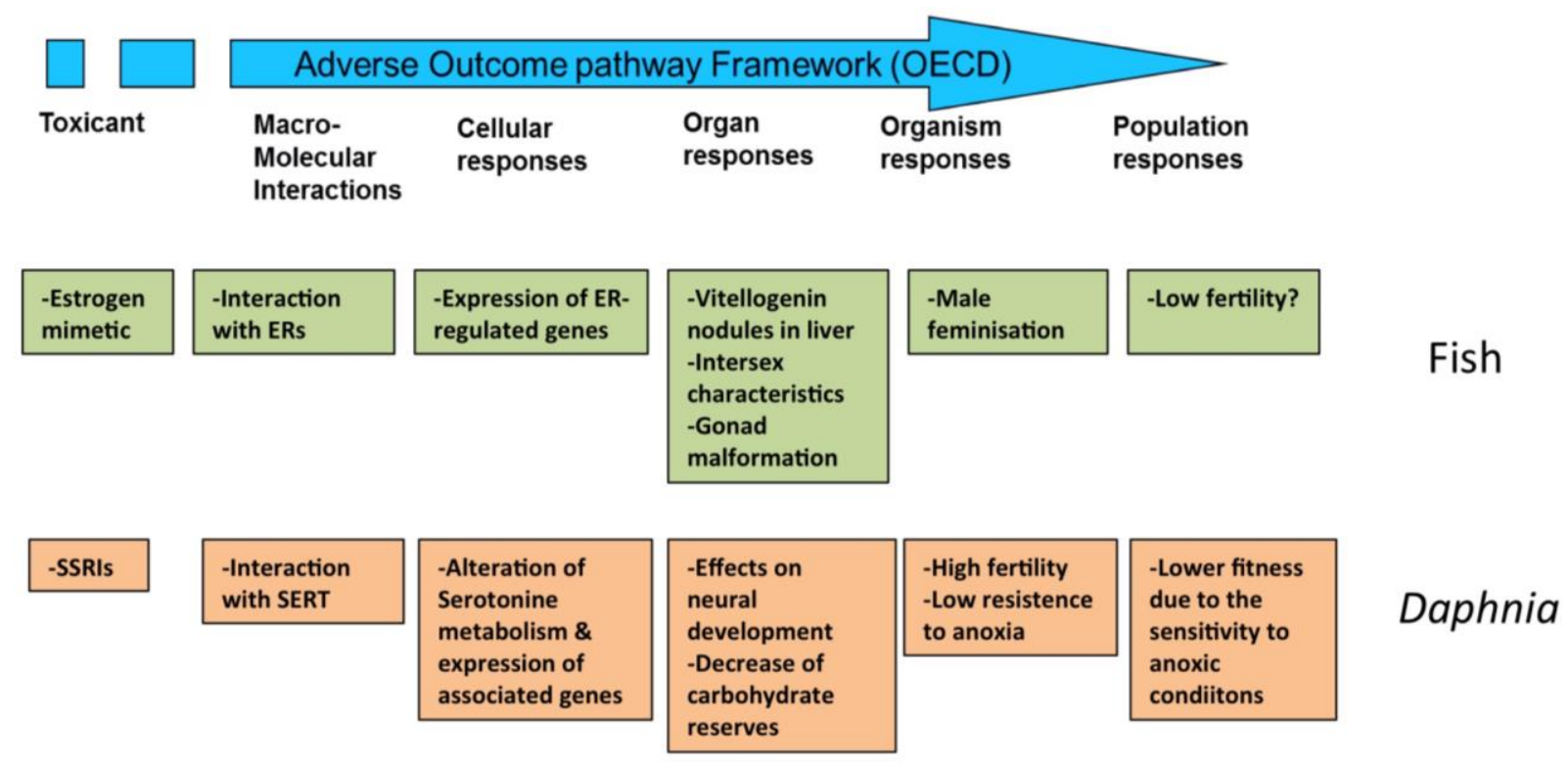

Fig. (6). Conceptual linkages across biological levels of organization. AOPs analyses integrated the different levels of organization, from molecular to population, for effects of endocrine disruptors, either "classical" (xenoestrogens in fish, green boxes) or "nonclassical" ones (neuroendocrine disruption in Daphnia, brown boxes). ER, estrogen receptors; SSRI selective serotonin reuptake inhibitors; SERT, serotonine transporter. Data from [82, 83].

The ever-increasing importance of the omic technologies in Ecotoxicology resulted in an overflow of data from multiple techniques and approaches that need to be analyzed, integrated and presented in a useful way to understand the implications at individual, population and ecosystem levels. AOP analyses are useful to tell apart, as well to correlate one which other, the initial (or "key") events of the toxic effects (i.e., endocrine disruption) and the truly adverse effects, those that compromise the health of the individuals, populations, and finally the ecosystems.

\section{CONFLICT OF INTEREST}

The authors confirm that this article content has no conflict of interest.

\section{ABBREVIATIONS}

$\begin{array}{lll}\text { 2DGE } & = & \text { Two-dimensional gel electrophoresis } \\ \text { AoP } & = & \text { Adverse outcome pathways } \\ \text { BPA } & = & \text { Bisphenol A } \\ \text { DES } & = & \text { Diethylstilbestrol } \\ \text { EDCs } & = & \text { Endocrine disrupting chemicals } \\ \text { GMA } & = & \text { Glycidyl Methacrylate }\end{array}$




$\begin{array}{lll}\text { LC } & = & \text { Liquid chromatography } \\ \text { MoA } & = & \text { Mode of action } \\ \text { mRNA } & = & \text { Messenger ribonucleic acid } \\ \text { MS } & = & \text { Mass spectrometry } \\ \text { NMR } & = & \text { Nuclear magnetic resonance } \\ \text { TF } & = & \text { Transcription factor }\end{array}$

\section{ACKNOWLEDGEMENTS}

This project was funded by the Spanish Ministry of Economy and Competitivenes (CTM2011-30471-C02-01) and the Catalan Government (2009SGR924 and 2014SGR642). We thank Rita Jordão for the control and JH-disrupted Daphnia pictures in Fig. (4).

\section{SUPPLEMENTARY MATERIAL}

Supplementary material is available on the publishers Web site along with the published article.

\section{REFERENCES}

[1] Landrigan PJ, Goldman LR. Children's vulnerability to toxic chemicals: a challenge and opportunity to strengthen health and environmental policy. Health Aff (Millwood) 2011; 30(5): 842-50. [http://dx.doi.org/10.1377/hlthaff.2011.0151] [PMID: 21543423]

[2] Snape JR, Maund SJ, Pickford DB, Hutchinson TH. Ecotoxicogenomics: the challenge of integrating genomics into aquatic and terrestrial ecotoxicology. Aquat Toxicol 2004; 67(2): 143-54. [http://dx.doi.org/10.1016/j.aquatox.2003.11.011] [PMID: 15003699]

[3] Bergman $\AA$, Becher G, Blumberg B, et al. Manufacturing doubt about endocrine disrupter science - A rebuttal of industry-sponsored critical comments on the UNEP/WHO report "State of the Science of Endocrine Disrupting Chemicals 2012". Regul Toxicol Pharmacol 2015; 73(3): $1007-17$.

[http://dx.doi.org/10.1016/j.yrtph.2015.07.026] [PMID: 26239693]

[4] O’Malley BW. Unified hypothesis for early biochemical sequence of events in steroid hormone action. Metabolism 1971; 20(10): 981-8. [http://dx.doi.org/10.1016/0026-0495(71)90019-9] [PMID: 5097685]

[5] Mangelsdorf DJ, Thummel C, Beato M, et al. The nuclear receptor superfamily: the second decade. Cell 1995; 83(6): 835-9. [http://dx.doi.org/10.1016/0092-8674(95)90199-X] [PMID: 8521507]

[6] Evans RM, Mangelsdorf DJ. Nuclear Receptors, RXR, and the Big Bang. Cell 2014; 157(1): 255-66. [http://dx.doi.org/10.1016/j.cell.2014.03.012] [PMID: 24679540]

[7] Bertrand S, Belgacem MR, Escriva H. Nuclear hormone receptors in chordates. Mol Cell Endocrinol 2011; 334(1-2): 67-75. [http://dx.doi.org/10.1016/j.mce.2010.06.017] [PMID: 20620189]

[8] Bertrand S, Brunet FG, Escriva H, Parmentier G, Laudet V, Robinson-Rechavi M. Evolutionary genomics of nuclear receptors: from twentyfive ancestral genes to derived endocrine systems. Mol Biol Evol 2004; 21(10): 1923-37. [http://dx.doi.org/10.1093/molbev/msh200] [PMID: 15229292]

[9] Frye CA, Bo E, Calamandrei G, et al. Endocrine disrupters: a review of some sources, effects, and mechanisms of actions on behaviour and neuroendocrine systems. J Neuroendocrinol 2012; 24(1): 144-59. [http://dx.doi.org/10.1111/j.1365-2826.2011.02229.x] [PMID: 21951193]

[10] European_Comission European Workshop on the Impact of Endocrine Disrupters on Human Health and Wildlife . Weybridge,UK: European Commission 1996.

[11] Colborn T. Environmental estrogens: health implications for humans and wildlife. Environ Health Perspect 1995; 103(Suppl)(7): 135-6.

[12] Cooper RL, Kavlock RJ. Endocrine disruptors and reproductive development: a weight-of-evidence overview. J Endocrinol 1997; 152(2): 159-66.

[http://dx.doi.org/10.1677/joe.0.1520159] [PMID: 9071972]

[13] Nielsen G, Gee D. The impacts of endocrine disrupters on wildlife, people and their environments. The Weybridge+15 (1996-2011) report, in EEA Technical Report 2012; 1-112.

[14] Schug TT, Janesick A, Blumberg B, Heindel JJ. Endocrine disrupting chemicals and disease susceptibility. J Steroid Biochem Mol Biol 2011; 127(3-5): 204-15. [http://dx.doi.org/10.1016/j.jsbmb.2011.08.007] [PMID: 21899826]

[15] Céspedes R, Petrovic M, Raldúa D, et al. Integrated procedure for determination of endocrine-disrupting activity in surface waters and sediments by use of the biological technique recombinant yeast assay and chemical analysis by LC-ESI-MS. Anal Bioanal Chem 2004; 378(3): 697-708. 
[http://dx.doi.org/10.1007/s00216-003-2303-5] [PMID: 14658021]

[16] Luo Y, Guo W, Ngo HH, et al. A review on the occurrence of micropollutants in the aquatic environment and their fate and removal during wastewater treatment. Sci Total Environ 2014; 473-474: 619-41. [http://dx.doi.org/10.1016/j.scitotenv.2013.12.065] [PMID: 24394371]

[17] Diamanti-Kandarakis E, Bourguignon JP, Giudice LC, et al. Endocrine-disrupting chemicals: an Endocrine Society scientific statement. Endocr Rev 2009; 30(4): 293-342. [http://dx.doi.org/10.1210/er.2009-0002] [PMID: 19502515]

[18] Lisa D, Arcand-Hoy LD, Benson WH. Fish reproduction: An ecologically relevant indicator of endocrine disruption. Environ Toxicol Chem 1998; 17: 49-57. [http://dx.doi.org/10.1002/etc.5620170108]

[19] Porte C, Janer G, Lorusso LC, et al. Endocrine disruptors in marine organisms: approaches and perspectives. Comp Biochem Physiol C Toxicol Pharmacol 2006; 143(3): 303-15.

[http://dx.doi.org/10.1016/j.cbpc.2006.03.004] [PMID: 16723279]

[20] Nakanishi T. Endocrine disruption induced by organotin compounds; organotins function as a powerful agonist for nuclear receptors rather than an aromatase inhibitor. J Toxicol Sci 2008; 33(3): 269-76. [http://dx.doi.org/10.2131/jts.33.269] [PMID: 18670157]

[21] Goulson D. Review: An overview of the environmental risks posed by neonicotinoid insecticides. J Appl Ecol 2013; 50(4): 977-87. [http://dx.doi.org/10.1111/1365-2664.12111]

[22] Grün F, Blumberg B. Environmental obesogens: organotins and endocrine disruption via nuclear receptor signaling. Endocrinology 2006; 147(6)(Suppl.): S50-5. [http://dx.doi.org/10.1210/en.2005-1129] [PMID: 16690801]

[23] Hutchinson TH. Small is useful in endocrine disrupter assessment--four key recommendations for aquatic invertebrate research. Ecotoxicology 2007; 16(1): 231-8. [http://dx.doi.org/10.1007/s10646-006-0107-z] [PMID: 17219089]

[24] Lafont R, Mathieu M. Steroids in aquatic invertebrates. Ecotoxicology 2007; 16(1): 109-30. [http://dx.doi.org/10.1007/s10646-006-0113-1] [PMID: 17238002]

[25] Matthiessen P, Gibbs PE. Critical appraisal of the evidence for tributyltin-mediated endocrine disruption in mollusks. Environ Toxicol Chem 1998; 17: 37-43.

[http://dx.doi.org/10.1002/etc.5620170106]

[26] Rotchell JM, Ostrander GK. Molecular markers of endocrine disruption in aquatic organisms. J Toxicol Environ Health B Crit Rev 2003; 6(5): 453-96. [http://dx.doi.org/10.1080/10937400306476] [PMID: 12888444]

[27] Servos MR. Review of the aquatic toxicity, estrogenic responses and bioaccumulation of alkylphenols and alkylphenol polyethoxylates. Water Qual Res J Canada 1999; 34(1): 123-77.

[28] Soin T, Smagghe G. Endocrine disruption in aquatic insects: a review. Ecotoxicology 2007; 16(1): 83-93. [http://dx.doi.org/10.1007/s10646-006-0118-9] [PMID: 17235670]

[29] Sumpter JP. Endocrine disrupters in the aquatic environment: An overview. Acta Hydrochim Hydrobiol 2005; 33(1): 9-16. [http://dx.doi.org/10.1002/aheh.200400555]

[30] Vos JG, Dybing E, Greim HA, et al. Health effects of endocrine-disrupting chemicals on wildlife, with special reference to the European situation. Crit Rev Toxicol 2000; 30(1): 71-133. [http://dx.doi.org/10.1080/10408440091159176] [PMID: 10680769]

[31] Paps J, Baguna J, Riutort M. Lophotrochozoa internal phylogeny: new insights from an up-to-date analysis of nuclear ribosomal genes. Proc Royal Biol Sci 1660; 276(1660): 1245-54.

[32] Edgecombe GD, Giribet G, Dunn CW, et al. Higher-level metazoan relationships: recent progress and remaining questions. Org Divers Evol 2011; 11: 151-72. [http://dx.doi.org/10.1007/s13127-011-0044-4]

[33] Bertrand S, Thisse B, Tavares R, et al. Unexpected novel relational links uncovered by extensive developmental profiling of nuclear receptor expression. PLoS Genet 2007; 3(11): e188. [http://dx.doi.org/10.1371/journal.pgen.0030188] [PMID: 17997606]

[34] LeBlanc GA. Crustacean endocrine toxicology: a review. Ecotoxicology 2007; 16(1): 61-81. [http://dx.doi.org/10.1007/s10646-006-0115-z] [PMID: 17235672]

[35] Fong PP, Ford AT. The biological effects of antidepressants on the molluscs and crustaceans: a review. Aquat Toxicol 2014; 151: 4-13. [http://dx.doi.org/10.1016/j.aquatox.2013.12.003] [PMID: 24374179]

[36] Piña B, Casado M, Quiros L. Analysis of gene expression as a new tool in ecotoxicology and environmental monitoring. Trends Analyt Chem 2007; 26: 1145-54.

[http://dx.doi.org/10.1016/j.trac.2007.09.009] 
[37] Piña B, Barata C. A genomic and ecotoxicological perspective of DNA array studies in aquatic environmental risk assessment. Aquat Toxicol 2011; 105(3-4)(Suppl.): 40-9. [http://dx.doi.org/10.1016/j.aquatox.2011.06.006] [PMID: 22099343]

[38] Barata C, Porte C, Baird DJ. Experimental designs to assess endocrine disrupting effects in invertebrates. A review. Ecotoxicology 2004; 13(6): 511-7. [http://dx.doi.org/10.1023/B:ECTX.0000037188.09072.de] [PMID: 15526857]

[39] Olmstead AW, LeBlanc GA. Insecticidal juvenile hormone analogs stimulate the production of male offspring in the crustacean Daphnia magna. Environ Health Perspect 2003; 111(7): 919-24. [http://dx.doi.org/10.1289/ehp.5982] [PMID: 12782492]

[40] Mu X, LeBlanc GA. Cross communication between signaling pathways: Juvenoid hormones modulate ecdysteroid activity in a crustacean. J Exp Zoology A Comp. Exp Biol 2004; 301(10): 793-801.

[41] Rodriguez EM, Medesani DA, Fingerman M. Endocrine disruption in crustaceans due to pollutants: A review. Comp Biochem Physiol Mol A Integr Physiol 2007; 146(4): 661-71. [http://dx.doi.org/10.1016/j.cbpa.2006.04.030]

[42] Di Poi C, Bidel F, Dickel L, Bellanger C. Cryptic and biochemical responses of young cuttlefish Sepia officinalis exposed to environmentally relevant concentrations of fluoxetine. Aquat Toxicol 2014; 151: 36-45. [http://dx.doi.org/10.1016/j.aquatox.2013.12.026] [PMID: 24439571]

[43] Di Poi C, Darmaillacq AS, Dickel L, Boulouard M, Bellanger C. Effects of perinatal exposure to waterborne fluoxetine on memory processing in the cuttlefish Sepia officinalis. Aquat Toxicol 2013; 132-133: 84-91. [http://dx.doi.org/10.1016/j.aquatox.2013.02.004] [PMID: 23474317]

[44] Fong PP. Zebra mussel spawning is induced in low concentrations of putative serotonin reuptake inhibitors. Biol Bull 1998; 194(2): 143-9. [http://dx.doi.org/10.2307/1543044]

[45] Gibbons MC, Castagna M. Serotonin as an inducer of spawning in 6 bivalve species. Aquacult 1984; 40(2): $189-91$. [http://dx.doi.org/10.1016/0044-8486(84)90356-9]

[46] Lazzara R, Fernandes D, Faria M, López JF, Tauler R, Porte C. Changes in lipid content and fatty acid composition along the reproductive cycle of the freshwater mussel Dreissena polymorpha: its modulation by clofibrate exposure. Sci Total Environ 2012; 432: 195-201. [http://dx.doi.org/10.1016/j.scitotenv.2012.05.094] [PMID: 22728965]

[47] Sakharov DA, Salanki J. Effects of dopamine antagonists on snail locomotion. Experientia 1982; 38(9): 1090-1. [http://dx.doi.org/10.1007/BF01955384]

[48] Uhler GC, Huminski PT, Les FT, Fong PP. Cilia-driven rotational behavior in gastropod (Physa elliptica) embryos induced by serotonin and putative serotonin reuptake inhibitors (SSRIs). J Exp Zool 2000; 286(4): 414-21. [http://dx.doi.org/10.1002/(SICI)1097-010X(20000301)286:4<414::AID-JEZ9>3.0.CO;2-B] [PMID: 10684564]

[49] Yeoman MS, Pieneman AW, Ferguson GP, Ter Maat A, Benjamin PR. Modulatory role for the serotonergic cerebral giant cells in the feeding system of the snail, Lymnaea. I. Fine wire recording in the intact animal and pharmacology. J Neurophysiol 1994; $72(3)$ : $1357-71$. [PMID: 7807217]

[50] Fingerman M. Crustacean endocrinology: a retrospective, prospective, and introspective analysis. Physiol Zool 1997; 70(3): $257-69$. [PMID: 9231399]

[51] Toyota K, Kato Y, Miyakawa H, et al. Molecular impact of juvenile hormone agonists on neonatal Daphnia magna. J Appl Toxicol 2014; 34(5): 537-44 [http://dx.doi.org/10.1002/jat.2922] [PMID: 24038158]

[52] Heckmann LH, Sibly RM, Connon R, et al. Systems biology meets stress ecology: linking molecular and organismal stress responses in Daphnia magna. Genome Biol 2008; 9(2): R40. [http://dx.doi.org/10.1186/gb-2008-9-2-r40] [PMID: 18291039]

[53] Ciocan CM, Cubero-Leon E, Peck MR, et al. Intersex in Scrobicularia plana: transcriptomic analysis reveals novel genes involved in endocrine disruption. Environ Sci Technol 2012; 46(23): 12936-42. [http://dx.doi.org/10.1021/es302948g] [PMID: 23110442]

[54] Leonard JA, Cope WG, Barnhart MC, Bringolf RB. Metabolomic, behavioral, and reproductive effects of the synthetic estrogen $17 \alpha-$ ethinylestradiol on the unionid mussel Lampsilis fasciola. Aquat Toxicol 2014; 150: 103-16. [http://dx.doi.org/10.1016/j.aquatox.2014.03.004] [PMID: 24667233]

[55] Sanchez BC, Ralston-Hooper K, Sepúlveda MS. Review of recent proteomic applications in aquatic toxicology. Environ Toxicol Chem 2011; 30(2): 274-82. [http://dx.doi.org/10.1002/etc.402] [PMID: 21072841]

[56] Ji C, Wu H, Wei L, Zhao J, Yu J. Proteomic and metabolomic analysis reveal gender-specific responses of mussel Mytilus galloprovincialis to 2,2',4,4'-tetrabromodiphenyl ether (BDE 47). Aquat Toxicol 2013; 140-141: 449-57. [http://dx.doi.org/10.1016/j.aquatox.2013.07.009] [PMID: 23938206]

[57] Janer G, Porte C. Sex steroids and potential mechanisms of non-genomic endocrine disruption in invertebrates. Ecotoxicology 2007; 16(1): 145-60. 
[http://dx.doi.org/10.1007/s10646-006-0110-4] [PMID: 17219086]

[58] Fernandes D, Porte C, Riva C, Bordonali S. Steroid acyltransferases regulate endogenous levels of testosterone and estradiol in the marine mussel Mytilus galloprovincialis. Comp Biochem Physiol A Mol Integra Physiol 2009; 154: S24-4.

[http://dx.doi.org/10.1016/j.cbpa.2009.05.084]

[59] Ho KK, Leung PT, Ip JC, Qiu JW, Leung KM. De novo transcriptomic profile in the gonadal tissues of the intertidal whelk Reishia clavigera. Mar Pollut Bull 2014; 85(2): 499-504.

[http://dx.doi.org/10.1016/j.marpolbul.2014.02.023] [PMID: 24629602]

[60] Iguchi T, Watanabe H, Katsu Y. Application of ecotoxicogenomics for studying endocrine disruption in vertebrates and invertebrates. Environ Health Perspect 2006; 114( Suppl (1)): 101-5.

[61] Ralston-Hooper KJ, Adamec J, Jannash A, Mollenhauer R, Ochoa-Acuña H, Sepúlveda MS. Use of GC $\times$ GC/TOF-MS and LC/TOF-MS for metabolomic analysis of Hyalella azteca chronically exposed to atrazine and its primary metabolite, desethylatrazine. J Appl Toxicol 2011; 31(5): 399-410.

[http://dx.doi.org/10.1002/jat.1587] [PMID: 20853443]

[62] Heckmann LH, Connon R, Hutchinson TH, Maund SJ, Sibly RM, Callaghan A. Expression of target and reference genes in Daphnia magna exposed to ibuprofen. BMC Genomics 2006; 7: 175. [http://dx.doi.org/10.1186/1471-2164-7-175] [PMID: 16827938]

[63] Heckmann LH, Sibly RM, Timmermans MJ, Callaghan A. Outlining eicosanoid biosynthesis in the crustacean Daphnia. Front Zool 2008; 5: 11. [http://dx.doi.org/10.1186/1742-9994-5-11] [PMID: 18625039]

[64] Fleury E, Moal J, Boulo V, et al. Microarray-based identification of gonad transcripts differentially expressed between lines of Pacific oyster selected to be resistant or susceptible to summer mortality. Mar Biotechnol (NY) 2010; 12(3): 326-39. [http://dx.doi.org/10.1007/s10126-009-9227-9] [PMID: 19813056]

[65] Hayashi Y, Heckmann LH, Callaghan A, Sibly RM. Reproduction recovery of the crustacean Daphnia magna after chronic exposure to ibuprofen. Ecotoxicology 2008; 17(4): 246-51. [http://dx.doi.org/10.1007/s10646-008-0191-3] [PMID: 18214676]

[66] Dai YJ, Jia YF, Chen N, et al. Zebrafish as a model system to study toxicology. Environ Toxicol Chem 2014; 33(1): 11-7. [http://dx.doi.org/10.1002/etc.2406] [PMID: 24307630]

[67] Merrick BA, Bruno ME. Genomic and proteomic profiling for biomarkers and signature profiles of toxicity. Curr Opin Mol Ther 2004; 6(6): 600-7. [PMID: 15663324]

[68] Garcia-Reyero N, Denslow ND. Applications of genomic technologies to the study of organochlorine pesticide-induced reproductive toxicity in fish. J Pestic Sci 2006; 31: 252-62.

[http://dx.doi.org/10.1584/jpestics.31.252]

[69] Ankley GT, Bencic DC, Breen MS, et al. Endocrine disrupting chemicals in fish: developing exposure indicators and predictive models of effects based on mechanism of action. Aquat Toxicol 2009; 92(3): 168-78. [http://dx.doi.org/10.1016/j.aquatox.2009.01.013] [PMID: 19261338]

[70] Kolle SN, Ramirez T, Kamp HG, et al. A testing strategy for the identification of mammalian, systemic endocrine disruptors with particular focus on steroids. Regul Toxicol Pharmacol 2012; 63(2): 259-78. [http://dx.doi.org/10.1016/j.yrtph.2012.04.004] [PMID: 22554500]

[71] van Ravenzwaay B, Kolle SN, Ramirez T, Kamp HG. Vinclozolin: a case study on the identification of endocrine active substances in the past and a future perspective. Toxicol Lett 2013; 223(3): 271-9.

[http://dx.doi.org/10.1016/j.toxlet.2013.03.029] [PMID: 23558297]

[72] Katsiadaki I, Williams TD, Ball JS, et al. Hepatic transcriptomic and metabolomic responses in the Stickleback (Gasterosteus aculeatus) exposed to ethinyl-estradiol. Aquat Toxicol 2010; 97(3): 174-87. [http://dx.doi.org/10.1016/j.aquatox.2009.07.005] [PMID: 19665239]

[73] Fuerhacker M. EU water framework directive and stockholm convention: can we reach the targets for priority substances and persistent organic pollutants? Environ Sci Pollut Res Int 2009; 16 (Suppl (1)): S92-7. [http://dx.doi.org/10.1007/s11356-009-0126-4]

[74] Raldua D, Campos B, Barata C, Pina B, Garcia Regero N, Babin PJ. Deciphering emerging toxicological effects of pharmaceuticals on aquatic organisms by using daphnia magna and danio rerio as model organisms analysis. Removal, effects and risk of pharmaceuticals in the water cycle - occurrence and transformation in the environment 2013; 62: 611-47.

[75] Russell W, Burch R. The principles of humane experimental techniques. London, UK: Methuen 1959.

[76] Raldúa D, Piña B. In vivo zebrafish assays for analyzing drug toxicity. Expert Opin Drug Metab Toxicol 2014; $10(5)$ : 685-97. [http://dx.doi.org/10.1517/17425255.2014.896339] [PMID: 24617455]

[77] Mrema EJ, Rubino FM, Brambilla G, Moretto A, Tsatsakis AM, Colosio C. Persistent organochlorinated pesticides and mechanisms of their toxicity. Toxicology 2013; 307: 74-88. [http://dx.doi.org/10.1016/j.tox.2012.11.015] [PMID: 23219589] 
[78] Frye CA. Endocrine-disrupting chemicals: elucidating our understanding of their role in sex and gender-relevant end points. Vitam Horm 2014; 94: 41-98. [http://dx.doi.org/10.1016/B978-0-12-800095-3.00003-1] [PMID: 24388187]

[79] Viñas R, Jeng YJ, Watson CS. Non-genomic effects of xenoestrogen mixtures. Int J Environ Res Public Health 2012; 9(8): $2694-714$. [http://dx.doi.org/10.3390/ijerph9082694] [PMID: 23066391]

[80] Wong RL, Walker CL. Molecular pathways: environmental estrogens activate nongenomic signaling to developmentally reprogram the epigenome. Clin Cancer Res 2013; 19(14): 3732-7. [http://dx.doi.org/10.1158/1078-0432.CCR-13-0021] [PMID: 23549878]

[81] Ankley GT, Bennett RS, Erickson RJ, et al. Adverse outcome pathways: a conceptual framework to support ecotoxicology research and risk assessment. Environ Toxicol Chem 2010; 29(3): 730-41. [http://dx.doi.org/10.1002/etc.34] [PMID: 20821501]

[82] Villeneuve L, Wang RL, Bencic DC, et al. Altered gene expression in the brain and ovaries of zebrafish (Danio rerio) exposed to the aromatase inhibitor fadrozole: microarray analysis and hypothesis generation. Environ Toxicol Chem 2009; $28(8)$ : $1767-82$. [http://dx.doi.org/10.1897/08-653.1] [PMID: 19422270]

[83] Campos B, Piña B, Barata C C. Mechanisms of action of selective serotonin reuptake inhibitors in Daphnia magna. Environ Sci Technol 2012; 46(5): 2943-50. [http://dx.doi.org/10.1021/es203157f] [PMID: 22324381]

[84] Heyland A, Hodin J, Reitzel AM. Hormone signaling in evolution and development: a non-model system approach. BioEssays 2005; 27(1): 64-75. [http://dx.doi.org/10.1002/bies.20136] [PMID: 15612033]

Received: June 11, 2014 Revised: May 11, 2015

Accepted: June 5, 2015

(C) Oliveira et al.; Licensee Bentham Open.

This is an open access article licensed under the terms of the Creative Commons Attribution-Non-Commercial 4.0 International Public License (CC BY-NC 4.0) (https://creativecommons.org/licenses/by-nc/4.0/legalcode), which permits unrestricted, non-commercial use, distribution and reproduction in any medium, provided the work is properly cited. 